\title{
ANALYSIS OF HEALTH TOURISM IN THE REPUBLIC OF SERBIA AND THE CZECH REPUBLIC
}

\author{
Bela Muhi ${ }^{1}$ \\ Jelena Vemić Đurković
}

DOI: https://doi.org/10.31410/tmt.2020.227

\begin{abstract}
Tourism is one of the most dynamic economic sectors, which is constantly evolving and differentiating. As a result of changing economic conditions and current social trends, the behavior of tourism participants who are looking for a more targeted and diverse offer is changing, which leads to the emergence of new and specific forms of tourism. One of these specific forms of tourism is health tourism.

This paper aims to analyze tourism in Serbia and the Czech Republic with a special focus on health tourism. The Czech Republic has become one of the top health tourism destinations in Europe. On the other side in Serbia, health tourism has been in the process of development and internationalization in the past few years. In order to successfully develop health tourism, Serbia should follow the example and learn from developed countries in this field, and that is why this paper will describe good examples from the Czech Republic.
\end{abstract}

Keywords: Tourism, Health tourism, Serbia, Czech Republic.

\section{INTRODUCTION}

Tealth is very important for our well-being and nowadays there are more and more people 1 who are willing to travel to receive health care or to enjoy wellness/spa programs. The most frequent reasons why tourists decide to travel for health care or wellness/spa include lower costs, getting treatment that is not available in their home country, advanced technologies or medical equipment, shorter waiting times, better quality, doctor's expertise and attitude to patients and also a lack of insurance.

According to a report issued by VISA in collaboration with Oxford Economics, the health tourism industry is estimated at a staggering \$439 billion. The growth rate is projected to be up to $25 \%$ per year for the next decade, as it is estimated that $3-4 \%$ of the world's population will travel abroad in search of health care and medical treatments, and about 11 million medical tourists are expected each year. Although the medical travel industry has been undervalued for years, this report points to growth factors - that the health tourism market will reach an astronomical figure of $\$ 3$ trillion by 2025 . The Medical Tourism Index (MTI) in its report lists the top health tourism destinations worldwide. Examining cross-border spending on medical services in more than 176 countries, the report showed that the United States has the largest share in the health tourism market in terms of consumption, while countries such as Thailand, Singapore, South Korea and in Europe Spain, Germany, Hungary and the Czech Republic are increasingly attracting tourists from around the world. ${ }^{3}$ The Czech Republic is one of the most popular health tourism destinations in Europe. The country offers modern spas, highly trained

\footnotetext{
$1 \quad$ University Educons, Vojvode Putnika bb, 21208 Sremska Kamenica, Serbia

2 University Educons, Vojvode Putnika bb, 21208 Sremska Kamenica, Serbia

3 More information: https://www.turistickisvet.com/ retrieved on 02.11.2020
} 
medical specialists, an excellent level of medical care, affordable prices, and a perfect place to recover after surgery.

Considering the importance of health tourism in the world the Tourism development strategy of the Republic of Serbia for the period from 2016 to 2025 highlights health tourism (together with its subcategories medical and spa/wellness tourism) as one of the key types of tourism in the country which has serious potential for attracting local and international tourists.

The capacities of health tourism in Serbia are significant. On the one hand, the main resources and opportunities are based on rich thermal-geological resources and springs of mineral water, as well as on the long-lasting tradition of using those resources for therapeutic purposes. On the other hand, this opportunity is also based on the existence of high standards of medical education and the accessibility of a certain type of high-quality medical services, for a significantly lower price than in other countries, which is suitable for the further development of health tourism in Serbia.

\section{HEALTH TOURISM}

Before the global Covid-19 pandemic situation, tourism was one of the most prosperous industries, which moved unstoppably forward with a rapidly improving economic situation and a higher standard of living. At the same time, it is perceived by most people in today's modern society as a part of life that is inseparable. People have more and more free time, they live at a higher level and they have a greater desire to get to know different forms of tourism and destinations. Demand for tourism is rising as the living standards of the population rise, the economy thrives, wages rise and technological development moves forward. At the same time, narrower segments of tourism participants are emerging, which have different wishes and requirements and travel for specific purposes. Špačková (2019) found that "some people may seek tourism for recreation, others may find activities related to movement and cognition in tourism, and others may perceive travel and tourism as their lifestyle and content". There are many types of tourism according to the motives. Authors Foret and Foretová (2001) divide tourism into: recreational, performed in an environment that is suitable for rest and improvement of physical and mental condition, cultural - cognitive, which is focused mainly on learning about history, culture, but also traditions and customs, religious (pilgrimage tourism), connected with the visit of sacred and pilgrimage sites, religious monuments, educational, the aim of which is to learn new things (languages, sports, etc.), social, focused on finding relatives or creating new friendly ties with people with the same interests, medical (spa-therapeutic), includes medical prevention, rehabilitation, convalescence, or also treatment of the consequences of diseases or injuries in health-friendly environments, sports, focused not only on their own sports activities, but also passive spectators at sports events, exploring nature (flora, fauna), when it comes mainly to visiting nature reserves or national parks, includes ecotourism adventurous (adrenaline sports), associated with dangerous activities, testing of mental and physical characteristics and skills of participants, professional, which includes various business trips, congress tourism, participation in exhibitions, political, focuses on meetings of political parties, shopping, includes shopping trips.

Even though people include tourism into their lives for many reasons (business, congress, ecology, visiting friends, cultural and/or spiritual enrichment, etc.), the most common and oldest reason to travel as a tourist is medical i.e. intending to improve health. 
Health tourism has a very long history. The concept of travelling for health care has been frequent since the Roman Empire. The purposes of the first forms of travelling were directly associated with well-being and better health. It can be confirmed by a large number of spas that are situated in Europe and other places.

Many authors who researched health tourism point out the fact that this is the "border area of medicine and tourism" or "shared field of healthcare and tourism".

Dunn (1959) stated, more than fifty years ago, the need for developing a new health paradigm in line with demographic, social, economic and policy changes. More recently, the widening of the "travel motivation basis", as well as higher living standards, which generate new health challenges and, consequently, the need for improved physical, mental and psychological states/ conditions, led to the multiplication or branching of tourism forms namely health tourism.

There are many different reasons for travelling for health care. According to Guy et al. (2015), "the most frequent arguments to travel for health care are lower costs, getting treatment that is not available in the home country, shorter waiting times, better quality and attractiveness of combination of vacation and medical treatment abroad". Tseng (2013) adds shortage of insurance, non-affordability as a result of high prices.

Today the resource base of health tourism consists of natural healing factors (medicinal thermo-mineral waters, medicinal clay, crude oil, healing climate), medical infrastructure, professional staff, etc. Table 1 shows the main factors of health travel decisions. The content of the stays is often supplemented with local monuments and cultural and gastronomic programs.

Table 1. The main factors of health travel decision

\begin{tabular}{|l|l|}
\hline Medical factors & Touristic factors \\
\hline - Reputation and skills of doctors & - Reputation as a tourist destination \\
- Results of medical treatments & - Price of a trip \\
- Price of treatment & - Developed infrastructure \\
- Insurance and guarantee & - Cultural closeness \\
- Follow-up and supporting services & - Safety and stability \\
- Foreign language skills & \\
\hline
\end{tabular}

Source: Milićević, S., Milovanović, V. \& Mandarić, M. (2013). Potentials of Serbia as medical tourism destination at the international tourism market, Actual Problems of Economics 142(4), pp. 401., Sziva, I. (2010). Gulliver: in the land of giants? The opportunities of the Hungarian initiations in the surgical medical touristic market, Annual Conference, Travel and Tourism Research Association Europe, Budapest, Hungary, pp. 338.

While following modern trends in health tourism, it is also important to mention the emerging term that is wellness tourism. Wellness is, above all, a lifestyle that leans towards optimal health and well-being ${ }^{4}$ where the body and mind become one. Wellness can be considered a state of well-being that combines the harmony of body, mind, and soul with self-responsibility, physical activity, cosmetic care, healthy eating, relaxation, meditation, mental activity, education and social contacts as its fundamental elements. Wellness tourism is treated as a subcategory of health tourism by some authors. Mueller (2001) defines wellness tourism as "the sum of all the relationships and phenomena resulting from a journey to a different place to proactively pursue activities that preserve or promote personal health and wellbeing". According to Miller (2005), wellness tourism can be defined as the "type of travel where tourists go on vacation to reach higher levels of wellness".

$4 \quad$ The term wellness is coined by blending two terms - well-being and fitness. 
One of the subcategories of health tourism is medical tourism. The combination of medicine and tourism is a relatively new type of tourism that is reaching a high rate of growth worldwide. Connell (2008) considers that "medical tourism, although being linked to direct medical treatments or interventions, should be the major concept to the detriment of health tourism." According to him, medical tourism is "where people travel, often long distances, to overseas destinations to obtain medical, dental and surgical care while simultaneously being holidaymakers, in a more conventional sense".

Smith and Puczko (2009) have defined medical tourism as "traveling to destinations to undergo medical treatments such as surgery or other specialist interventions". Therefore, medical tourism is described as the travel to a distinct place to achieve a specific cure for a disease, ailment, or condition, taken by patients who are looking for lower costs, higher quality, better access and/ or different health care. This definition highlights the 'requisite' to travel for medical purposes, i.e., being illness-oriented because the primary travel motivation is related to the cure or treatment of a particular illness or medical condition.
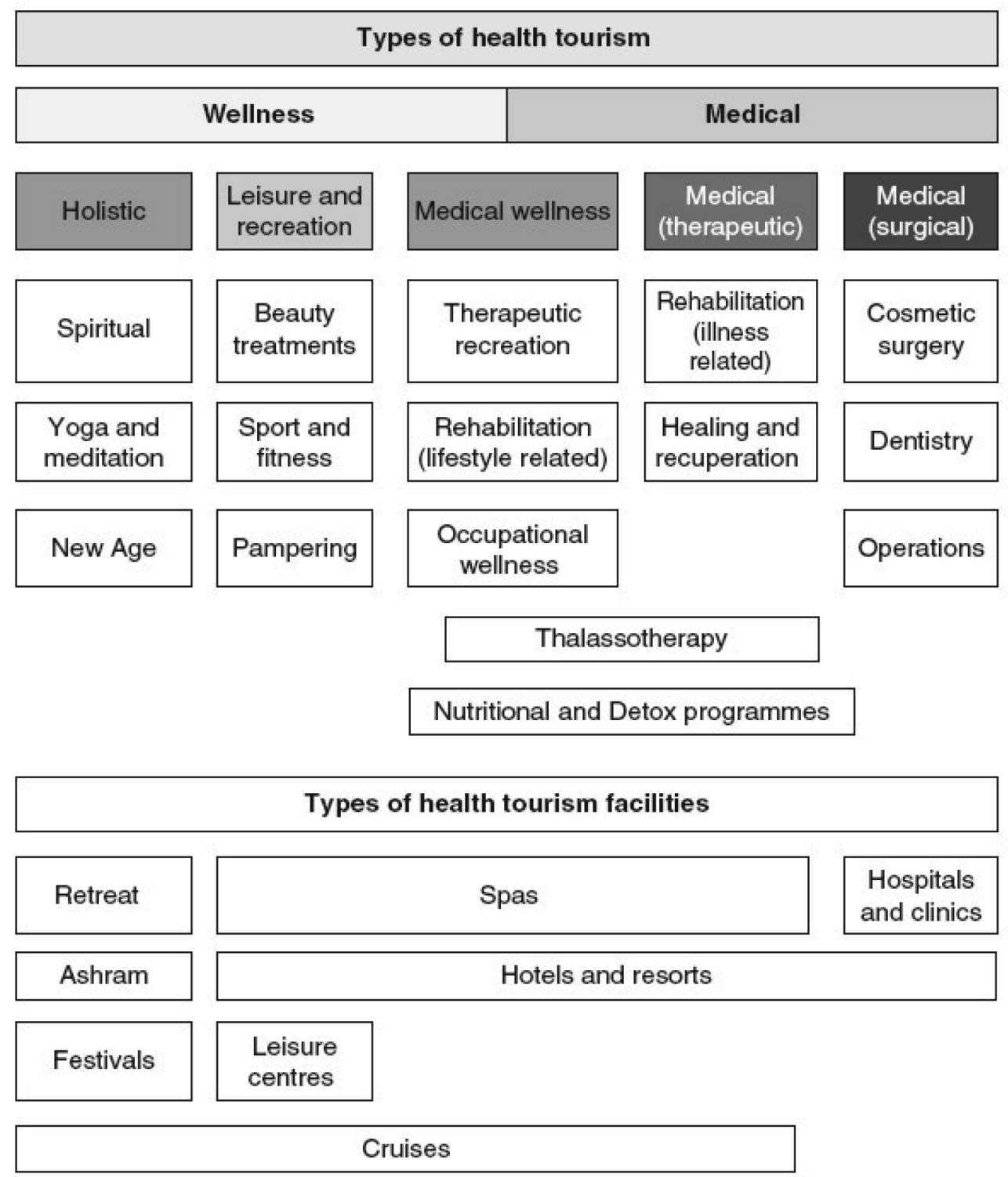

Figure 1. Types and facilities of health tourism

Source: Smith, M. \& Puczko, L. (2009). Health and Wellness Tourism, Oxford: Elsevier, pp. 7. 
Medical tourism can have two major forms: surgical and therapeutic. There is a clear distinction between the two. Surgical certainly involves certain operation(s), whereas therapeutic means participating in healing treatments.

An increasingly frequent reason for travel is medical services and the reason behind that is the price of medical services in receptive countries that are often lower when compared to the countries where tourists come from.

Complex medical treatments require the services of specialized medical institutions and expert medical staff. So, it is a matter of trips that have the goal to offer different, often serious medical services such as surgery, organ transplants, plastic surgery, dental interventions, etc.

Besides the price, the key factor in the medical tourism destination offer is the standard of the medical services, the expertise of the medical staff and the technological equipment of the hospitals and offices which offer such services, as well as the attractiveness of the destination itself. The concentration of medical institutions is usually higher in larger urban environments. Aside from medical services, medical tourism arrangements also include accommodation (mainly in hotels of higher quality), excursions, tours, etc.

Package deals of health and medical services in the form of organized travel are a modern trend in the tourism market. Globalization of the world's economy has led to the globalization of the health and medical market. Several specialized travel agencies around the world organize package deals for traveling abroad where health programs or surgeries are combined with a pleasant vacation. Figure 1 shows the types and facilities of health tourism.

\section{HEALTH TOURISM IN SERBIA}

Serbia, as a country with a rich cultural and historical heritage and preserved natural resources, has comparative advantages for the development of tourism. In addition to prehistoric archeological sites, ancient heritage, numerous monuments and fortresses, Serbia also has medieval churches and monasteries, some of which are UNESCO World Heritage Sites. Serbia has several mountains, rivers, lakes, mineral springs, national parks, etc. Although it is continental, it also has connections with distant seas across the Danube. It connects Western Europe and the Middle East and therefore has geopolitical significance, and it is no wonder that it has been the target of invaders for centuries.

According to Milovanović and Miličević (2014) "despite many attractions, Serbian tourism is not sufficiently developed or commercialized in the international tourism market, because tourism as an industry has never had strategic importance in Serbia's development policy.“ Despite that, in recent years the numbers of tourists are increasing, especially foreign ones. Major destinations for foreign tourists are Belgrade and Novi Sad, while domestic tourists prefer spas and mountain resorts.

The origin of tourism in Serbia is connected to the abundance of thermal and mineral springs, so much, that history of Serbian tourism is sometimes equated to the history of Serbian spas (Serbian word for spa, banja, became part of numerous toponyms). Some of them had a wider historical and evolutionary impact as remains of the prehistoric habitats have been discovered around them. Serbia has over 1000 cold and warm mineral water springs, and a great wealth 
of natural mineral gases and medicinal mud. In over 53 thermal locations, where even ancient Romans had enjoyed, spa therapies have been adapted to treat a wide range of health ailments and diseases. Besides the rich medicinal water spas, Serbia has "climatic spas", which have been designated health resorts thanks to their favorable climate and geographical location.

Milićević (2013) considers that "only in recent years, the spas of Serbia are starting to develop wellness tourism". The beginning is related to 2005 when the Special Hospital "Merkur" in Vrnjačka Banja opened the first wellness center in the spas of Serbia, called "Fons Romanus". Next year, "Merkur" opens the aqua center "Water Fall", then the peloid center "Limus Romanus", and others. This concept of health tourism is slowly beginning to be accepted by other spa centers in Serbia through the opening of modern wellness centers in Banja Koviljača, Soko Banja, Banja Kanjiža, Ribarska Banja, Prolom Banja, Niška Banja, etc. This greatly contributes to the change of the old-fashioned image of Serbian spas - they are visited not only by the old and the sick but also by healthy people of different ages.

Hrabovski-Tomić, E. (2007) divide spas in Serbia into two basic categories:1) Spa hospitals, which receive patients whose costs are covered by social insurance. Those hospitals are under the jurisdiction of the health authorities, although they can receive individuals with personal payment, they are not market and tourist-oriented (e.g. Jodna Banja in Novi Sad). 2) Tourist spas that, in addition to treatment and rehabilitation, offer other forms of restoring and maintaining good health and psychophysical ability with thermo-mineral water, air, healing mud, etc. These treatments are designed as tourist services and offered in the tourism market. These services-treatments can be partially paid through social security if such contracts are concluded (e.g. Banja Kanjiža).

Table 2. Influx of Tourists in Leading Spas in the Republic of Serbia from 2013 to 2015

\begin{tabular}{|c|c|c|c|c|c|c|}
\hline \multirow[b]{2}{*}{ Resort } & \multicolumn{3}{|l|}{ Arrivals } & \multicolumn{2}{|c|}{\begin{tabular}{|l|} 
Overnights \\
\end{tabular}} & \multirow[b]{2}{*}{2015} \\
\hline & 2013 & 2014 & 2015 & 2013 & 2014 & \\
\hline Vrnjačka Banja & 135,162 & 123,155 & 146,208 & 531,574 & 431,455 & 481,150 \\
\hline Sokobanja & 49,041 & 39,682 & 37,154 & 301,179 & 209,058 & 184,022 \\
\hline Bukovička Banja & 20,755 & 22,640 & 23,248 & 55,499 & 53,824 & 54,998 \\
\hline Mataruška Banja & 4,496 & 2,509 & 1,161 & 44,760 & 23,883 & 12,712 \\
\hline Banja Koviljača & 16,591 & 11,581 & 11,387 & 150,677 & 113,259 & 83,476 \\
\hline Prolom Banja & 10,963 & 9,552 & 11,284 & 55,428 & 51,998 & 64,921 \\
\hline Gornja Trepča & 8,528 & 8,486 & 8,323 & 87,623 & 85,514 & 84,429 \\
\hline Vranjska Banja & 4,424 & 3,887 & 2,366 & 31,532 & 22,691 & 19,872 \\
\hline Banja Kanjiža & 7,411 & 8,095 & 8,082 & 38,941 & 39,108 & 42,065 \\
\hline Banja Junaković & 5,385 & 5,388 & 6,011 & 37,477 & 45,396 & 45,725 \\
\hline Banja Vrdnik & 15,095 & 12,210 & 15,404 & 72,869 & 52,911 & 57,410 \\
\hline Banja Rusanda & 3,473 & 2,238 & 1,992 & 27,111 & 20,286 & 18,714 \\
\hline Banja Palić & 12,764 & 14,005 & 14,557 & 25,700 & 28,099 & 25,427 \\
\hline Selters Banja & 6,710 & 6,844 & 5,771 & 145,879 & 139,163 & 122,943 \\
\hline Lukovska Banja & 10,719 & 10,380 & 11,108 & 69,516 & 72,760 & 77,534 \\
\hline Gamzigradska Banja & 4,160 & 2,946 & 2,171 & 58,871 & 32,594 & 23,511 \\
\hline Ribarska Banja & 7,074 & 6,578 & 6,772 & 49,864 & 49,197 & 47,134 \\
\hline Sijarinska Banja & 5,269 & 5,250 & 5,626 & 49,653 & 46,648 & 46,049 \\
\hline Banja Vrujci & 8,639 & 6,995 & 8,767 & 37,238 & 26,874 & 36,446 \\
\hline Niška Banja & - & 3,260 & 3,178 & - & 29,511 & 29,991 \\
\hline
\end{tabular}

Source: Tourism development strategy of the Republic of Serbia for the period from 2016 to 2025 and Statistical Yearbook of the Republic of Serbia, 2011 - 2016, Statistical Release - Catering and Tourism Statistics 
Newer data on the number of spa visits is difficult to find, but older data can be useful also. The traffic of tourists in spas in Serbia for the period 2013-2015 (Table 2) shows certain oscillations, but growth is noticeable in several, such as Bukovička spa, Vrnjačka Banja, Prolom Banja, etc. and their offer is significantly enriched with the wellness facilities and have become centers of spa and wellness tourism in Serbia. Vrnjačka Banja is on the leading position for years. In 2015 Vrnjačka Banja registered 146,208 visitors and had 481,150 overnight stays and is also the second most visited tourist destination in Serbia, right after Belgrade. Spa tourism in Serbia is characterized by the extraordinary domination of domestic tourists, while visits of foreign tourists are on an extremely low level.

Analyzing the data in Table 2, we can see that the traffic of tourists in spas in Serbia grew every year. According to Perić et al. (2018), this result is related to "the beginning of the modernization of traditional spa and health resorts in Serbia, which in addition to basic health resort features introduced spa and wellness programs in their offer. With the opening of wellness centers in the spas, the tourist offer of spas has been expanded and enriched, which attracted many tourists. With this in mind, the further development of spas in Serbia should go precisely in this direction, and work on the modernization of traditional spas so that they can become, not only destinations for treatment and rehabilitation but also a place for rest and relaxation".

Medical tourism has been in the process of development and internationalization in the past few years in Serbia. Even though organized health and medical tourism is still developing, our medical and health facilities have offered for years various health services to foreigners. They come in individually, without the mediation of specialized agencies. Stomatology has the biggest interest among foreigners, as well as surgeries from the field of laparoscopy, plastic surgery, artificial insemination, but also the services of rehabilitation in spas. Besides professional staff, other reasons for the arrival of foreigners are the prices as well, which are significantly lower than in their native countries. Domestic and local health organizations have exceptional medical staff, which is potentially a foundation for gaining an advantage over the competition in providing services of health tourism, especially medical tourism.

Table 3. Comparative review of the price of medical services in Serbia and abroad

\begin{tabular}{|l|l|l|}
\hline Medical services & Serbia & Foreign countries \\
\hline Colonoscopy & $200 €$ & $2.000 €$ (England) \\
\hline Dialysis & $120 €$ & $150 €$ (Slovenia) \\
\hline Cataract surgery & $1.200 €$ & $2.300-4.000 €$ (France and England) \\
\hline Lip augmentation & $400 €$ & $800 €$ (Europe) \\
\hline Nose correction & $2.500 €$ & $10.000 €$ (Europe) \\
\hline Implants & $2.500-3.000 €$ & $15.000 €$ (Germany) \\
\hline Teeth whitening & $200-270 €$ & $1.400-2.300 €$ (England) \\
\hline Tooth extraction & $20 €$ & $100 €$ (Europe) \\
\hline Fixed prosthesis & $600-1.000 €$ & $3.000 €$ (Europe) \\
\hline
\end{tabular}

Source: Ignjatijević, S., \& Čavlin, M. (2016). The analysis of the offers of medical tourism in Serbia. TISC Tourism International Scientific Conference Vrnjačka Banja, 1(1), pp. 75., based on: http://www.belmedic.rs/ General-hospital/107/pricelist.shtm

According to data from the National Association of Tourist Agencies of Serbia (YUTA), our country is much less expensive when it comes to dental tourism as the prices are up to $50 \%$ lower than in other European countries. In terms of plastic surgery, the prices are lower by 35 
to $40 \%$, in orthopedics by $30 \%$, while the quality of services in many segments is even better than the services on the rest of the continent. It is estimated that all of the expenses, including the treatment, post-operational medical care, transport, and accommodation, cost the same as a third of the surgery expenses in Western Europe. Table 4 shows the comparative review of the price of medical services in Serbia and some foreign countries.

According to data from YUTA, the number of health tourists in our country increases by 10 to $15 \%$ annually, and on an annual basis, there are currently between 40,000 and 60,000 visitors.

At the end of 2016, the Ministry of Health has called a competition for choosing private practice dental offices and offices for cosmetic surgery that will deal with health tourism, and which will be promoted by the country. A special board has been formed, including members of the Dental Chamber, Association of Aesthetic Plastic Surgery and ministry inspectors, that is going to control whether the offices are meeting the criteria.

The Ministry of Health, in cooperation with the Ministry of Tourism, has started to award certificates for health tourism to dental offices and offices for cosmetic surgery. In 2017, the first certificates have been awarded to private healthcare institutions which satisfied the terms of participation in the Project of Development and Promotion of Health Tourism in Serbia. The call for participation is always open, and by now, more than 130 healthcare institutions have applied, 60 of which received their certificates. It is believed that these certificates awarded by the state represent a certain guarantee for international patients that they will receive a quality and efficient service, not only a cheap one.

At the International Tourism Fair in Berlin and Moscow, in 2017, Serbia has promoted its health tourism for the first time. Contacts with tour-operators and insurance companies that deal with health insurance have been made.

\section{HEALTH TOURISM IN THE CZECH REPUBLIC}

The Czech Republic attracts millions of tourists annually, who come here to visit and admire some of the finest Cubist, Art Nouveau and Baroque buildings in Europe. The country has rich traditions, history and culture, as well as amazing sightseeing. The Czech Republic has a lot to offer, from chateaux and castles reminding of the powerful families, to hilltop ruins, spa towns, green forests, and good food. ${ }^{5}$

For the last 30 years, the Czech Republic has become one of the major tourist destinations in Europe, receiving 10,6 million foreign visitors' arrivals in 2018, equal to the local population. The country ranks 10th on the list of outbound tourism destinations in the European Union (EU), with Spain, Italy, and France on the top.

The most important types of tourism in the Czech Republic are recreational tourism, especially supported are forms of active holidays (e.g. cycling, winter sports) and sightseeing tourism. Spa tourism and congress tourism have a traditionally important place. From the point of view of the place of implementation, urban tourism is developing significantly, as well as rural tourism within the support of rural development. According to Jarolímková (2018) "under the influence

\footnotetext{
5 More information: https:/www.placidway.com/country/59/Czech-Republic-Medical-Tourism, retrieved on
} 13.11.2020 
of campaigns, the demand for specific topics in tourism, such as film tourism, gastronomic tourism, ecotourism, medical tourism, adventure tourism, beer or even dark tourism and others, is increasing in fashion waves."

The Czech Republic has become one of the top health tourism destinations in Europe. The country offers highly-trained specialists, an excellent level of medical care, affordable prices, and a perfect place to recover after surgery.

The Czech Republic has a long history of medical and pharmaceutical education, many Czech scientists have won international awards for their achievements. The Czech Republic has been a pioneer in many medical discoveries and developments. The soft contact lens and the discovery of the polarographic methods of analysis have been accomplished by two Czech professors. All the clinics and hospitals in the country know how important it is to offer high-quality medical care and experienced surgeons. After joining the European Union in 2004, the Czech Republic took important steps towards Western medical standards. The Czech Republic has the largest share of doctors per 1,000 inhabitants among all newer EU members.

The country is renowned for its excellent results in oncology, cardiology, infertility and eye surgery and procedures. Patients coming here have access to state-of-the-art robotic surgery, which implies faster recovery time, shorter hospital stay and significantly decreased possibility of complications.

According to Kotíková (2013) "The Czech Republic has very good conditions for the development of health tourism. These are not only favorable prices, perfect diagnostics, a high level of treatment processes, highly qualified staff and modern equipment. Other reasons are the long tradition of spa treatment, which persists in the awareness of potential patients, as well as the number of attractions of tourism and, last but not least, the good transport accessibility and location in the middle of Europe. Many medical facilities offer treatment to patients from abroad. The basic prerequisite for the development of health tourism is not dominantly top medical technology, but especially medical teams, helpful staff and language skills.“

As in Serbia, spa tourism has a famous and long history in the Czech Republic. Havránková (2019) stated that "spa tourism has become very popular; the profits of spa companies are rising and the number of guests is growing every year. Spa treatment is of preventive, curative and relaxing importance, while it is focused on the restoration of the physical and mental strength of using healing natural resources, such as treatment of the consequences of diseases. Natural healing resources, which include natural waters, peloids, hot spring gases and climatic conditions, are a prerequisite for the existence of natural healing spas.“

The most important spas in the Czech Republic include Karlovy Vary, Františkovy Lázně and Mariánské Lázně. Thanks to its own deposits of healing peat, Lázně Bohdaneč, Lázně Bělohrad or Bechyně are also frequently visited. The famous spas in Jeseník and Lázně Kynžvart are famous for their climatic conditions.

According to Speier (2011), a Czech spa resembles traditional "watering places" that have sources of mineral or thermal springs. The term lázně, or spa, in the Czech Republic, denotes a place that administers balneotherapy, or treatments that use natural sources like mineral waters, the gas that comes from the earth, mud, or peat bogs. People visit Czech spas for an average of three 
weeks and undergo various treatments that are prescribed by the spa doctor. Balneotherapy is a traditional Czech healing technique, which involves complex drinking and bathing therapies, as it is increasingly being incorporated into the development of a Czech health tourism industry. In the post-socialist period, the Czech economy relies heavily on tourism as a source of revenue, and spa towns are the second most popular attraction after Prague.

According to Vystouil (2017) "spas have always been attractive tourism centers with significant economic benefits in the Czech Republic. The privatization and transformation of the spa sector after 1989 brought several fundamental changes. The transformation in 1992 contributed to the formation of more than 50 new spa organizations from originally 12 state spa organizations. Despite some negative aspects (e.g., the temporary extinction of some smaller spas), there was a significant increase in the standard range of treatment stays for new forms of relaxation and regeneration stays (health tourism).“

There are currently 36 spa resorts in the Czech Republic that are grouped under the headquarters of the Association of Spa Resorts of the Czech Republic. Table 4 shows spa resorts in the Czech Republic (bed capacity and attendance). The spa resorts use natural resources, which are divided into the categories of thermal, muddy, radon, mud, climatic and mineral baths. The visitor can choose not only the type of bath but also the way of accommodation or meals, the length of stay, relaxation and wellness procedures. Guests can also take part in many cultural activities or take excursions into the surroundings of the spa. The spa towns have not only the unmistakable charm of architecture, but they also allow the visitor to enjoy the comfort combined with ancient healing procedures. The modern trend includes fitness, preventive health and the so-called wellness stays in the spa. Thanks to the traditions and reputation of the Czech spa resorts and clientele from upper middle classes with above-average expenditures, the spa is one of the key forms of active tourism.

The government of the Czech Republic is investing heavily in health and medical infrastructure and marketing campaigns to promote health tourism. The country has already become very popular among the British, but now the government is focusing on other regions, such as Russia, Germany, Switzerland, etc.

Table 4. Spa resorts in the Czech Republic - bed capacity and attendance 2015

\begin{tabular}{|c|c|c|c|c|}
\hline number of beds & number of guests & $\begin{array}{c}\text { number } \\
\text { of overnights stays }\end{array}$ & $\begin{array}{c}\text { \% overnight stays } \\
\text { of foreigners }\end{array}$ & $\begin{array}{c}\text { average } \\
\text { overnight stays }\end{array}$ \\
\hline 51,960 & 1,309 & 8,104 & 40 & 6,2 \\
\hline
\end{tabular}

Source: Vystouil, J., Šauer, M., \& Bobková, M. (2017). Spa, Spa Tourism and Wellness Tourism in the Czech Republic. Czech Journal of Tourism, 6(1), pp. 14.

\section{DISCUSSION}

High medical costs and large waiting lists for medical services in developed countries, as well as affordable prices of traveling, altogether with high-quality medical services in developing countries, have contributed to health tourism development in Serbia and the Czech Republic also.

Increasing interest for health tourism destinations in Serbia and the Czech Republic is connected with potential savings due to high medical costs and long waiting lists in developed countries, global trend of the population aging, high-quality surgeries at affordable prices with skilled personnel, high level of care, the accessibility of international air travel and high-quality accommodation. 
Serbia and the Czech Republic have great potential for the development of health tourism. The capacities of health tourism are based on rich thermal-geological resources and springs of mineral water, also on the existence of high standards of medical services, for a significantly lower price than in other countries.

The most frequent reasons why tourists decide to travel to Serbia for health care or wellness/spa include lower costs, getting treatment that is not available in their home country, advanced technologies or medical equipment, shorter waiting times, etc. Stomatology has the biggest interest among foreigners, as well as surgeries from the field of laparoscopy, plastic surgery, artificial insemination, but also the services of rehabilitation in spas.

Unfortunately, compared to Eastern and Middle European countries, health tourism in Serbia has not been sufficiently developed. While countries from the region have earlier recognized the opportunity for health tourism development, Serbia still lacks agencies specialized in health/medical tourism whose task would be to attract foreign patients and organize their stay. So far, medical services were provided to the Serbs who are temporarily employed abroad and visit their home country during the summertime, as well as to the citizens of other ex-Yugoslavian Republics.

According to Ignjatijević and Čavlin (2016) the reasons for the health tourism in Serbia being underdeveloped are the following:

- System of state health insurance prevents foreigners to use medical services in Serbia in large numbers. The reform of the health insurance system would create better conditions for the usage of medical tourism, although individual macroeconomists argue that it is easier to control costs of health when there is one source of funding (e.g. taxes and contributions), than in cases where funding is fragmented, from multiple sources;

- Disorderly and inefficient regulatory system that hampers the operations of government health institutions in terms of providing additional medical services. At the same time, the focus of management of state hospitals is mostly on the provision of additional funds that is the critical point of the managing process. Namely, when managers believe that everything can be fixed with money, it often happens that providing additional funding becomes their only mission;

- Poor transport infrastructure is another limiting factor in the development of medical tourism. The choice of hotels is poor and patients generally have expensive hotels or hostels, which often do not have adequate apartments;

- The big problem is the poor advertising and promotion of medical tourism and a lack of private-public partnerships in the field of health;

- The problem that we have been facing for many years is the departure of key medical personnel abroad, which results in a deficit of both specialists and managers.

The Ministry of Health of the Republic of Serbia in 2018 started the health tourism project. According to the information received by the Ministry of Health, before the project was established, 30,000 foreign patients arrived, and by recent estimates, in 2019 we had more than 100,000 patients who used health tourism services. The opinion of the Ministry of Health is that the quality of services within health tourism should be prioritized and that the best way to promote services is to produce patients satisfied with the received service. In its last report from December 2019, the Ministry of Health stated that ten new dental offices received certification and that there are currently more than 100 offices that belong to the program of Ministry of Health. It was reported that the national airline also joined the program and provided certain benefits when it comes to plane tickets. It is important 
to mention the fact that the Ministry of Health favors dental services and plastic and reconstructive surgery services. Still, the available database does not include all service providers.

As well as in the Czech Republic huge potential for health tourism belongs to Serbian spas and their rehabilitation centers. Serbia has over 1000 cold and warm mineral water springs, and a great wealth of natural mineral gases and medicinal mud. In over 53 thermal locations, where even ancient Romans had enjoyed, spa therapies have been adapted to treat a wide range of health ailments and diseases and involve drinking medicinal water or taking medicinal baths. Serbian spas have all the preconditions to be positioned as health tourism destinations due to: natural curative factor, medical indications, skilled medical personnel, equipped special hospitals, different types of accommodation, affordable prices, spa\&wellness supply, sport and recreation, culture and entertainment. Basic comparative advantages of Serbian spa tourism, according to Milićević (2013), are reflected in an "exceptionally rich natural medicinal resources, rich cultural and historical heritage, long balneological tradition, quality medical staff, skilled techniques of treatment, relatively low prices of accommodation and treatment as much as a variety of events that complement the stay of visitors." On the other side Ignjatijević and Čavlin (2016) found that "the factors that are slowing Serbia on the way to the international market are inadequate transport and municipal infrastructure, large representation outdated supply, an inadequate health-tourism product, lack of awareness of health tourism in line with modern trends in the market positioning of health tourism."

The Czech Republic has seized this opportunity by joining the EU. The Czech Republic has become one of the top health tourism destinations in Europe. The country offers highly-trained specialists, an excellent level of medical care, affordable prices, and a perfect place to recover after surgery. Wellness/spa tourism is also very popular, the profits of spa companies are rising and the number of guests is growing every year. Spa destinations offer preventive, curative and relaxing treatments. Natural healing resources, which include natural waters, peloids, hot spring gases and climatic conditions, are a prerequisite for the existence of natural healing spas.

As was done in the Czech Republic, modernization of spa capacities is needed in Serbia, as well as the introduction of new services and contents adapted for the tourism industry and healthcare service. On a global scale, there is a permanent increase in demand for specialized health and recreational centers and spas that offer a combination of medical treatment, rehabilitation, and recreation. The notion of traditional spas is changing all over the world and they are incorporating newer, more attractive activities and programs that follow modern trends. More precisely, the existing offer of spas, based on using natural healing resources and the basic services of boarding houses, has been abandoned a long time ago. These kinds of offers have been substituted with modern concepts of development, based on an offer of all kinds of attractive programs with different purposes because these modern variations are more attractive to a greater number of potential users. Such programs include sports recreation, programs for a natural and balanced diet, health checkups, health education and similar. These health and recreational programs are a part of a global offer of spas, intended for big groups of users such as healthy people who are experiencing high levels of stress, psycho-physical burden and other inconvenient factors of the environment; people suffering from obesity, milder forms of hypertension, diabetes, hyperlipidemia and other regulatory, metabolic and functional disorders; seniors, patients in the phase of convalescence, after suffering from severe diseases or surgeries, individuals with psycho traumas; athletes in phases of preparation and recovery, and so on.

By modernization of spa capacities in Serbia, as well as the introduction of new services and contents more domestic and foreign tourists could be attracted to visit. 


\section{CONCLUSION}

Today, programs of health tourism are one of the fastest-growing segments of the world's tourism offers. That is so not only because of the demographic changes, especially the aging of the baby boomer generation that is the biggest consumer of today's health tourism but also because of some general changes in social values that put more emphasis on a healthy lifestyle.

Health tourism of today generates a significant number of travelers and significant financial traffic on the international level, and their development affects the development of national healthcare systems. Thus, health tourism also has a strong economic significance for the destinations where such a type of tourist activity can be organized. The significance includes direct financial effects (paying for services) and indirect effects (increase in existing accommodation capacities, the consummation of different hospitality services, etc.)

In today's climate, healthcare has become a global market, with emerging, developing and developed nations competing for health tourists. Through the last few decades, health tourism destinations have appeared worldwide. Millions of tourists from all over the world travel for health reasons and visit different destinations each year. Both Serbia and the Czech Republic are looking for their place in the market. Having seen the huge potential market, both countries are investing in the promotion of the country as a health tourism destination. The capacities of health tourism in Serbia are significant; following the good practices of developed countries in the field of health tourism, such as the Czech Republic, Serbia could become a regional leader in health tourism.

\section{REFERENCES}

Connell, J. (2008). Tummy tucks and the Taj Mahal?: Medical tourism and the globalization of health care. In Woodside, A. \& Martin, D. (Eds.). Tourism management analysis, behaviour and strategy. Wallingford: CABI Publishing. pp. 232-244.

Dašić, D. (2018). Menadžment zdravstvenog i medicinskog turizma - mogući pravci razvoja u Republici Srbiji, Ekonomski signali, 2018, 13(1). pp 041-056.

Dunn, H. (1959). High-level wellness for man and society. American Journal of Public Health and the Nations Health, 49(6), pp. 786-792.

Foret, M. \& Foretová, V. (2001). Jak rozvijet mistní cestovní ruch. Praha: Grada Publishing, a.s.

Guy, B. S., Henson J. L.N. \& Dotson M. J. (2015). Characteristics of consumers likely and unlikely to participate in medical tourism." International Journal of Healthcare Management 8(2): pp. 68-76.

Havránková, A. (2019). Specifické formy cestovního ruchu. Liberec: Technická univerzita Hesková, M. (2006). Cestovní ruch - pro VOŠ A VŠ. Praha: Fortuna.

Hrabovski-Tomić, E. (2007). Destinacije zdravstvenog turizma (sa osvrtom na banje Vojvodine), Novi Sad: Prometej

https://www.placidway.com/country/59/Czech-Republic-Medical-Tourism, retrieved on 13.11.2020 https://www.turistickisvet.com/ retrieved on 02.11.2020

https://www.zdravlje.gov.rs - Ministry of Health of the Republic of Serbia

Ignjatijević, S., \& Čavlin, M. (2016). The analysis of the offers of medical tourism in Serbia. TISC - Tourism International Scientific Conference Vrnjačka Banja, 1(1), pp. 70-87. Retrieved from http://www.tisc.rs/proceedings/index.php/hitmc/article/view/209

Jarolímková, L. (2018). Cestovní ruch České republiky. Praha: VŠE 
Kotíková, H. (2013). Nové trendy v nabidce cestovních ruchu: nové produkty z hlediska motivace účastniků cestovniho ruchu: nové trendy v nabídce turismu pro specifické skupiny: názorné př́klady ze zahraniči i z České republiky. Praha: Grada Publishing, a.s.

Milićević, S. \& Petrović, J. (2017). Tourist products in the function of improving competitiveness of Serbia as a tourist destination. TISC-Tourism International Scientific Conference Vrnjačka Banja, 2(1), pp. 167-183.

Milićević, S. (2013). Health tourism - megatrend on the tourist market, Megatrend Review, 10(4), pp. $163-175$.

Milićević, S., Milovanović, V. \& Mandarić, M. (2013). Potentials of Serbia as medical tourism destination at the international tourism market, Actual Problems of Economics 142(4). pp. 397-404.

Miller, J. (2005). Wellness: The history and development of a concept. Spektrum Freizeit, 1, pp. 84-102.

Milovanović, V. \& Miličević, S. (2014). Upravljanje turističkim proizvodom Srbije u funkciji unapređenja konkurentnosti na međunarodnom turističkom tržištu, Menadžment $u$ hotelijerstvu i turizmu, 2(1), pp. 38-48.

Mueller, H., \& Kaufmann, E. (2001). Wellness tourism: Market analysis of a special health tourism segment and implications for the hotel industry. Journal of Vacation Marketing, 7(1), pp. 5-17.

Muhi, B., Kovačević, J. (2010). Resursna osnova i pregled tržišnih potencijala wellness turizma u Vojvodini, časopis Turističko poslovanje, 6/2010. pp. 99-109.

Nemeckova, E. (2016). Medical Tourism within the Czech Republic. Prague: Charles University in Prague, Faculty of Social Sciences

Perić, G., Stojiljković, M., Gašić, M., Ivanović, V., (2018). Perspectives of development of spa tourism in Serbia, Journal of Awareness, 2(1), pp. 597- 614

Smith, M. \& Puczko, L. (2009). Health and Wellness Tourism, Oxford: Elsevier.

Špačková, P. (2019). Turismus a jeho vliv na Národní park České Švýcarsko. Liberec: Technická univerzita v Liberci.

Spasojević, M., Šušić, V. (2011). Savremene tendencije u razvoju zdravstvenog turizma u svetu i Srbiji, časopis Teme, 2011/1, pp. 149-162.

Speier, A. (2011). Health Tourism in a Czech Health Spa, Anthropology and Medicine, 18/1, pp.125-136.

Stanković, S. (2009). Banje Srbije, Beograd: Zavod za izdavanje udžbenika

Statistical Yearbook of the Republic of Serbia, 2011 - 2016, Statistical Release - Catering and Tourism Statistics

Strategija razvoja turizma Republike Srbije za period od 2016. do 2025. godine (Tourism development strategy of the Republic of Serbia for the period from 2016 to 2025)

Sziva, I. (2010). Gulliver: in the land of giants? The opportunities of the Hungarian initiations in the surgical medical touristic market, Annual Conference, Travel and Tourism Research Association Europe, Budapest, Hungary, pp. 338.

Tseng, H. (2013). Medical health care tourism: Why patients go overseas and what nurse practitioners need to know. International Journal of Healthcare Management 6(2), pp. 132-135.

Vystouil, J., Šauer, M., \& Bobková, M. (2017). Spa, Spa Tourism and Wellness Tourism in the Czech Republic. Czech Journal of Tourism, 6(1), pp. 5-26.

Yuta - Nacionalna asocijacija turističkih agencija Srbije, http://www.yuta.rs/turisticke-agencije 